J. Perinat. Med. 12 (1984) 147

\section{Severe neonatal anemia possibly caused by spontaneous cephalic version, with excellent outcome - a case report}

\author{
J. Franckx, L. Sacre-Smits
}

Department of Pediatrics, Neonatal Unit, Academic Hospital - The Free University of Brussels, Belgium

\section{Introduction}

Anemia in the newborn due to occult blood loss may be the result of bleeding of the fetus into the maternal circulation. Severe anemia at birth secondary to an acute and massive fetomaternal hemorrhage is commonly associated with a poor prognosis. The authors present the case of a primipara with breech presentation who had a spontaneous cephalic version before giving birth to a severely anemic boy.

\section{Case report}

A 29-year-old primigravid woman was admitted to the hospital two days before her expected date of confinement because of a sudden decrease in fetal movements percieved. The fetus had presented by the breech until the 38th week of gestation. Between 38 and 39 weeks' gestation, spontaneous

\section{Curriculum vitae}

JOHAN FRANCKX, born in Brussels, studied medicine at the Free University of Brussels (flemisch section). He graduated in 1980 and started specializing in pediatrics at the St. Pieters and Academic Hospital in Brussels (Direction Prof. H. LOEB). Presently he has a scholarship at the University department of pediatrics, division of pediatric gastroenterology, Kinderspital Zürich.

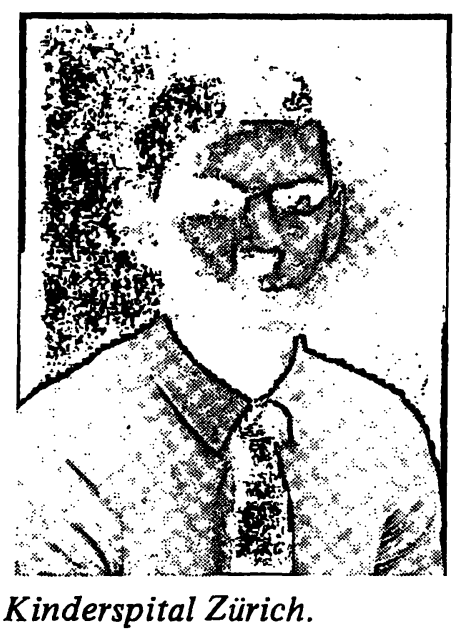

version had occurred. Her blood group was A-Rhpositive. An external cardiotocography that was performed on admission showed an episode of fetal bradycardia ( 70 beats per minute) without great variability. Labor was induced by extraamniotic instillation of prostaglandin $\mathrm{F}_{2 \alpha}$. During

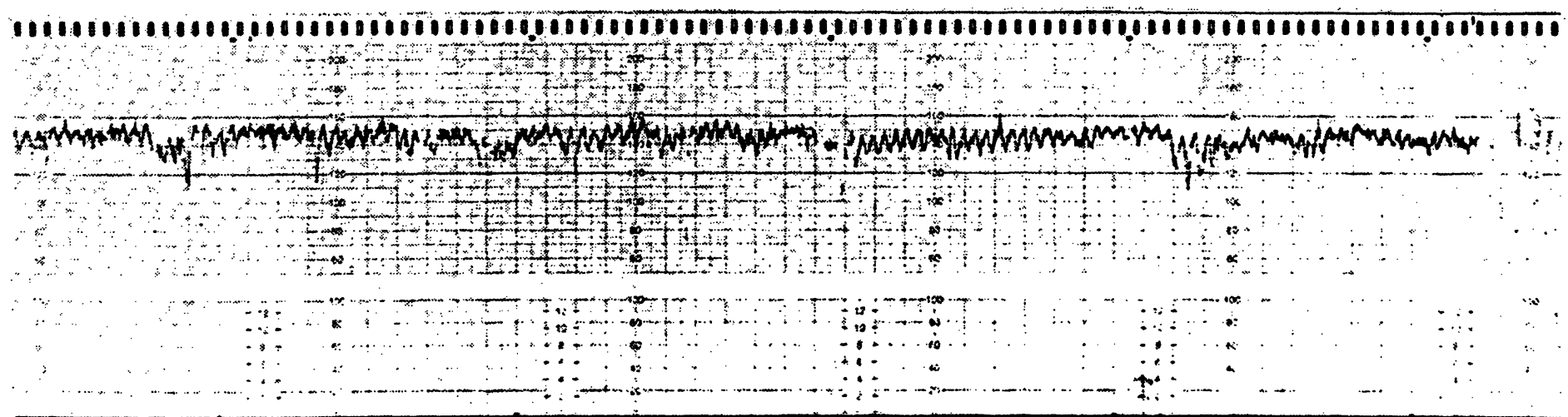

Fig. 1. FHR during first stage of labor, paper chart $1 \mathrm{~cm} / \mathrm{min}$. 


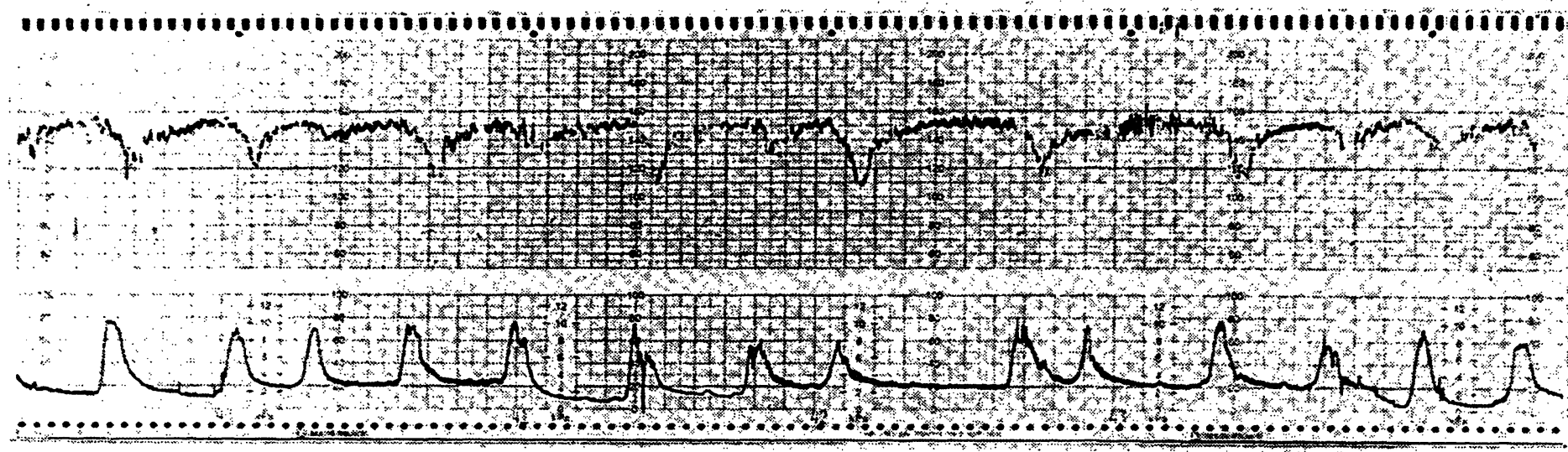

Fig. 2. FHR monitoring during second stage of labor.

labour fetal heart rate (FHR) monitoring showed an undulating sinusoidal pattern over a period of $45 \mathrm{~min}$ (Fig. 1). Prior to delivery significant late FHR decelerations were noted (Fig. 2). The mother gave birth to a male infant weighing 3250 g. No problems were apparent during expulsion. However, the 1 minute APGAR score was 1. The baby was strikingly pale and flaccid; no respiratory movements were noted. After aspiration of the nasopharynx, administration of $40 \%$ oxygen by facemask and insertion of a catheter in the umbilical vein by which isotonic saline was given, breathing started and the heart rate rose to above 100 per minute. Voluntary movements however were not seen and the baby stayed very pale. The placenta was grossly unremarcable: no intervillous thrombi, placental infarcts or retroplacental hematomata. Fifteen min after birth, the infant being hemodynamically stable, the results of the laboratory examinations performed on cord blood were obtained: $\mathrm{pH} 7.05$, hemoglobin $2.9 \mathrm{~g} / \mathrm{dl}$, hematocrit $10.5 \%$, bilirubin $0.5 \mathrm{~g} / \mathrm{dl}$. A control examination on blood obtained by heel prick confirmed these results: hemoglobin $4.3 \mathrm{~g} / \mathrm{dl}$, hematocrit $15 \%$, platelets $140 \times 10^{9} / 1$, nucleated cells $88 \times 10^{9} / 1$, (polymorphonuclears $10 \%$, lymphocytes $22 \%$, monocytes $1 \%$, ery throblasts $67 \%$ ). The uncorrected reticulocyte count was $12.2 \%$. An acid elution test showed the presence of $9.1 \%$ of fetal red cells in the maternal circulation. After a transfusion of $35 \mathrm{ml}$ packed cells followed the next day by $50 \mathrm{ml}$ of total blood the hemoglobin had risen to $10.7 \mathrm{~g} / \mathrm{dl}$. On the second day the baby developed an acute functional renal failure which responded well to fluid restriction and furosemide administration. Upon discharge, 10 days after birth, the physical examination and laboratory values of the infant were almost normal: hemoglobin $10.8 \mathrm{~g} / \mathrm{dl}$, hematocrit $32 \%$, platelets $273 \times 10^{9} / 1$, nucleated cells $5.2 \times 10^{9} / 1$ with $8 \%$ erythroblasts. During and after his hospitalisation the neonate recieved iron supplements and vitamine $\mathrm{C}$ orally. At this time the child is two years old and thriving well.

\section{Discussion}

While hemolytic disease accounts for most cases, fetal blood loss may be the second commenest cause of anemia at birth. Anemia in the newborn due to blood loss may be the result of obstetrical accidents, internal hemorrhage or occult hemorrhage prior to birth [12]. Obstetrical accidents and internal hemorrhages can be readily recognised and anticipated. Occult blood loss prior to birth is seen in the twin transfusion syndrome or may be caused by bleeding of the fetus into the maternal circulation.

WEINER [17] had suggested the existence of this latter entity for the first time, but it was not until the introduction by KLEIHAUER and BETKE [4] of the acid elution technique that the occurrence of feto-maternal hemorrhage could be demonstrated. In approximately $50 \%$ of all pregnancies a small number of fetal cells penetrate the maternal circulation whereas in $1 \%$ the larger number of fetal cells suggest a massive transfusion exceeding $40 \mathrm{ml}$ [1]. The reason for such a transfusion of fetal red cells into the maternal circulation remains 
obscure. COHEN [1] and LUBIN [5] have suggested that such hemorrhages are a normal finding due to the trauma of labour. Several authors have stressed that their incidence is increased by external cephalic version $[2,6,8,13]$, traumatic amniocentesis $[9,16]$ and cesarian section [11]. As illustrated by the present case, spontaneous cephalic version may possibly account for another cause of feto-maternal transfusion resulting in severe neonatal anemia.

A sinusoidal fetal heart rate pattern has been previously described in association with severe Rh-disease [7] and feto-maternal transfusion [10]. By most authors it is considered as indicative of severe fetal jeopardy and is commonly associated with a bad prognosis. Treatment should consist in delivery if gestational age is consistent with neonatal viability [14].

\section{Summary}

A 29-year-old primipara with breech presentation had a spontaneous cephalic version a few days before her admission. She was hospitalised because of a sudden decrease in fetal movements perceived. During labour a sinusoidal fetal heart rate pattern was observed. The mother gave birth to a strikingly pale $3250 \mathrm{~g}$ weighing boy. His APGAR score was $1 / 5 / 6$. Cord hemoglobin was $2.9 \mathrm{~g} / \mathrm{dl}$ and an acid elution test showed the presence of $9.1 \%$ fetal red cells in the maternal circulation. Following a transfusion of packed cells and total blood, the babies hemoglobin rose to above $10 \mathrm{~g} / \mathrm{dl}$. On the second day of life he developed an acute functional renal failure which responded well to fluid restriction and furosemide administration. Upon discharge, 10 days after birth, the physical
Severe neonatal anemia secondary to an acute and massive hemorrhage is commonly associated with a poor prognosis (mortality rate over $50 \%$ ) [3]. An acute bleeding resulting in the loss of $20 \%$ of the blood volume will result in shock in the neonatal period [15]. With $9.1 \%$ of fetal red blood cells in the maternal circulation, the amount of fetomaternal hemorrhage can be estimated at $360 \mathrm{ml}$ [1]. This equals 1.3 times the total blood volume of a $3.250 \mathrm{~g}$ weighing baby. This feto-maternal transfusion occurred probably over a 1 week period and according to the characteristics set by NATHAN and OSKI [12], it has to be considered as an acute fetal blood loss.

Under such conditions prompt re-expansion of blood volume proved to be life saving.

and neurological examination were normal. At present time the child is two years old and thriving well.

Anemia in the newborn due to occult blood loss may be the result of bleeding of the fetus into the maternal circulation. The incidence of a massive transplacental blood loss is increased by traumatic amniocentesis, by external cephalic version and during cesarian section. As illustrated by the present case, spontaneous cephalic version may possibly account for another cause of fetomaternal transfusion resulting in severe neonatal anemia.

Severe anemia at birth secondary to an acute and massive feto-maternal hemorrhage is commonly associated with a poor prognosis. Under such conditions immediate re-expansion of the blood volume proved to be life saving.

Keywords: Fetal version, feto-maternal transfusion, neonatal anemia.

\section{Zusammenfassung}

Spontane Drehung in Schädellage als Ursache einer schweren neonatalen Anämie - Fallstudie.

Bei einer 29jährigen Erstpara mit Steißlage erfolgte einige Tage vor der Einweisung eine spontane Drehung in Schädellage. Die Aufnahme erfolgte wegen plötzlicher Abnahme der Kindsbewegungen. Während der Wehen wurde ein sinusoidales Herzfrequenzmuster beobachtet. Die Mutter wurde von einem auffallend blassen, $3250 \mathrm{~g}$ schweren Jungen entbunden. Der APGAR-Score betrug 1/5/6. Der Hb-Wert im Nabelvenenblut lag bei $2,9 \mathrm{~g} / \mathrm{dl}$. Mit dem Säureelutions-Test wurden 9,1\% fetale Ery throzyten im mütterlichen Blut nachgewiesen. Nach Gabe von Erythrozytensediment und Vollblut stieg der $\mathrm{Hb}$-Wert des Kindes auf über $10 \mathrm{~g} / \mathrm{dl}$. Am zweiten Lebenstag ent- wickelte sich ein akutes Nierenversagen. Nach Flüssigkeitsrestriktion und Furosemidgabe bildete es sich jedoch rasch zurück. Die Entlassungsuntersuchung ergab am 10. Tag p.p. einen normalen körperlichen und neurologischen Befund. Das Kind ist inzwischen zwei Jahre alt und entwickelt sich gut.

Eine neonatale Anämie durch okkulten Blutverlust kann die Folge einer fetalen Blutung in den mütterlichen Kreislauf sein. Die Häufigkeit transplazentarer Blutungen ist bei traumatischen Amniozentesen, äußeren Wendungen und Sectiones erhöht. Wie in unserem Fall, kann auch eine spontane Drehung in die Schädellage die Ursache einer feto-maternalen Transfusion und damit einer schweren, neonatalen Anämie sein. 
Die durch eine massive feto-maternale Blutung bedingte schwere Anämie bei der Geburt hat in der Regel eine schlechte Prognose. Die sofortige Auffüllung des Blutvolumens ist in diesen Fällen lebensrettend.

Schlüsselwörter: Fetale Drehung, feto-maternale Transfusion, neonatale Anämie.

\section{Résumé}

Observation d'un cas d'anémie néonatale sévère probablement provoquée par une version céphalique spontanée.

Les auteurs présentent le cas d'une primipare âgée de 29 ans ayant une présentation du siège. Le fœtus s'était versé spontanément quelques jours avant son admission à l'hôpital à cause d'une diminution brutale des mouvements actifs fu fœtus. Au cours du travail un rythme cardiaque fœtal sinusoïdal a été observé. A la naissance, nous trouvions devant un garçon extrêmement pâle pesant $3250 \mathrm{~g}$. Son score d'APGAR était de $1 / 5 / 6$. L'hémoglobine prélevée au cordon était de $2,9 \mathrm{~g} / \mathrm{dl}$. Par la technique d'élution acide de KLEIHAUER nous trouvions 9,1\% d'hématies fœtales dans le sang maternel. Après une transfusion de culot globulaire ainsi que de sang frais, l'hémoglobine s'élevait au dessus de $10 \mathrm{~g} / \mathrm{dl}$. Pendant le second jour de vie, l'enfant développait une insuffisance rénale aigüe, laquelle répondait bien à une restriction hydrique et à l'administration de furosémide. Au moment de la sortie, au dixième jour après la naissance, l'examen physique et neurologique de l'enfant était normal. Actuellement, le garçon est âgé de deux ans et il se développe correctement.

L'anémie du nouveau-né causée par une hémorragie occulte peut provenir d'une transfusion fœto-maternelle. Le risque d'une telle transfusion foto-maternelle est augmenté par une amniocentèse traumatique, une version céphalique par manoeuvres externes ou une césarienne. Comme l'illustre le cas présenté, une version céphalique spontanée peut être une autre cause de transfusion fœto-maternelle avec anémie néonatale sévère.

Une anémie grave à la naissance, secondaire à une hémorragie fœto-maternelle s'associe le plus souvent à un mauvais pronostic. Dans des conditions pareilles l'expansion immédiate du volume sanguin est indispensable pour la survie du nouveau-né.

Mots-clés: Anémie néonatale, transfusion fœto-maternelle, version céphalique.

\section{Bibliography}

[1] COHEN, F., W. W. ZUELzER, D. C. GUSTAFSON et al.: Mechanisms of isoimmunisation. I. The transplacental passage of fetal erythrocytes in homospecific pregnancies. Blood 23 (1964) 621

[2] DONALDSON, I.A.: A case of transplacental haemorrhage. J. Obstet. Gynaec. Brit. Cwlth. 70 (1963) 512

[3] KIRKMAN, H. N., H. D. RILEY: Posthemorrhagic anemia and shock in the newborn. A review. Pediatrics 24 (1959) 97

[4] KleihaUeR, E., H. BRAUN, K. BETKE: Demonstration von fetalem Hämoglobin in den Erythrocyten eines Blutausstrichs. Klin.Wschr. 35 (1957) 637

[5] LUBIN, B.: Neonatal anaemia secondary to blood loss. Clin. Haemotol. 7 (1978) 19

[6] LUYET, F., J. SCHMID, E. MARONI et al.: Massive feto-maternal transfusion during external cephalic version, with fatal outcome. Arch. Gynäk. 221 (1976) 273

[7] MANSEAU, P., J. VAQUiER, J. ChavinNE: Le rythme cardiaque fœtal «sinusoidal». Aspect évocateur de souffrance fœtale au cours de la grossesse. J. Gynecol. Obstet. Biol. Reprod. 1 (1971) 343

[8] MARCUS, R. G., H. CREWE-BROWN, S. KRAWITZ et al.: Feto-maternal haemorrhage following successful and unsuccessful attempts at external cephalic version. Brit. J. Obstet. Gynaec. 82 (1975) 578

[9] MISENHEIMER, H. R.: Fetal hemorrhage associated with amniocentesis. Amer. J. Obstet. Gynec. 94 (1966) 1133

[10] MONDANLOU, H. D., R. K. FREEMAN, O. ORTIZ et al.: Sinusoidal fetal heart rate pattern and severe fetal anemia. Obstet. Gynecol. 49 (1977) 537
[11] MONTAGUE, A.C.W., J.R.KREVANS: Transplacental hemorrhage in cesarean section. Amer. J. Obstet. Gynec. 95 (1966) 1115

[12] NATHAN, D.G., F.A. OSKI: Hematology of infancy and childhood. 2nd Edn, W.B. Saunders Company, London 1982

[13] POLLOCK, A.: Transplacental haemorrhage after external cephalic version. Lancet I (1968) 612

[14] VISSER, G. H. A.: Antepartum sinusiodal and decelerative heart rate patterns in $\mathrm{Rh}$ disease. Am. J. Obstet. Gynecol. 143 (1982) 538

[15] WALlgREN, G., J. S. HANSON, J. LIND: Quantitative studies of the human neonatal circulation. III. Observations on the newborn infant's central circulatory response to moderate hypovolemia. Acta Pead. Scand. (suppl) 179 (1967) 43

[16] WOO WANG, M. Y.F., E. MCCUTCHEON, J. F. DESFORGES: Fetomaternal hemorrhage from diagnostic transabdominal amniocentesis. Amer. J. Obstet. Gynec. 97 (1967) 1123

[17] WIENER, A. S.: Diagnosis and treatment of anemia in the newborn caused by occult placental hemorrhage. Amer. J. Obstet. Gynec. 56 (1948) 717

Received February 14, 1984. Revised March 23, 1984. Accepted March 27, 1984.

\author{
Dr. J. Franckx \\ Academic Hospital V.U.B. \\ Laarbeeklaan 101 \\ B-1090 Brussels \\ Belgium
}

